\title{
CHILDREN, NATION AND REACTORS: IMAGINING AND PROMOTING NUCLEAR POWER IN CONTEMPORARY UKRAINE ${ }^{1}$. \\ Tatiana Kasperski
}

\begin{abstract}
:
This article examines public communication in the domain of the peaceful nuclear technology as an important vector in the political, institutional and technological transformations of Ukraine's nuclear industry over the three decades that followed the collapse of the USSR. An important aspect of this article is the analysis of the children's drawings of nuclear power stations produced for artistic contests organized by Ukrainian local nuclear information centers. These contests and other information center activities contributed to the increased visibility of nuclear power. They helped define the relationship between the public and the industry, projected an ideal representation of how the citizens should engage technology and were a part of the inscription of the atom into complex representations about the Ukrainian nation, its past, present, traditions and modernity. Analysis of these drawings as well as government and nuclear power station (NPP) documents, press articles, interviews, indicates that the notion of the "domestication" of the atom is a particularly appropriate way to describe the process of banalization of nuclear technologies in Ukraine. It captures the on-going effort to make the atom more domestic, familiar, human, accessible, and "banal" against the not-so-distant backdrop of the radiological, political and social fallout of Chernobyl nuclear disaster in 1986, when the country was still part of the Soviet Union.
\end{abstract}

Key words: Ukraine, nuclear energy, banalization, public and technology

If you visit the information centers situated near the four operating nuclear power stations in Ukraine, you will most certainly notice the wonderful children's drawings exhibited on their walls. Using folk motives and bright colors, they depict in an often naïve and cheerful manner local nuclear installations surrounded by happylooking women and children, birds, flowers, lakes, churches and angels, and the warm sun overhead. Local hosts will proudly explain to you that these drawings were

\footnotetext{
${ }^{1}$ This project has received funding from the European Union's Horizon 2020 research and innovation programme under the Marie Sklodowska-Curie grant agreement n ${ }^{\circ} 705577$ (TechPolChange) and from the Euratom research and training programme 2014-2018 under grant agreement $n^{\circ} 662268$ (History of Nuclear Energy and Society - HoNESt).
} 
selected among the many works sent to the artistic competitions that are organized by the information centers and coordinated by Energoatom, the state enterprise that operates all fifteen Ukrainian reactors. Such drawing contests existed already in the $1990 \mathrm{~s}$, but became particularly popular in the 2000s. The four nuclear power station (NPP) information centers announce these artistic competitions annually. Children living within 30 and up to 100 kilometers diameter zones are encouraged to send their works to an information center jury that will select several of the most striking drawings to participate in a second round of competition at the national level. Children sometimes also submit handicrafts or animated movies. The number of participants may vary, but often reach one hundred per station. The majority of the participants are girls. The best works usually win cash prizes.

These contests can be analyzed both as examples of cultural representations of nuclear energy in Ukraine, and as part of the on-going effort to make the atom more domestic, familiar, human, accessible, and "banal" against the not-so-distant backdrop of the Chernobyl nuclear disaster in 1986, when the country was still part of the Soviet Union. What does this effort to sponsor children's drawings tell us about nuclear public communication in contemporary Ukraine? What is specific to the postSoviet and post-Chernobyl context? How does the Ukrainian case help us to understand the banalization of nuclear objects and the role of fun, childhood, nation and nature in this process?

To answer these questions this paper will draw on printed sources (local newspapers, journals, promotional brochures), visits to two of the information centers, several hundred of the drawings pictures entered into the drawing contests, and which I found either on the web pages of the information centers or in the archives of the two centers I visited, as well as my participation as an observer in the jury for two of those contests in April 2016. To my knowledge, the quantity and quality of the drawings is unparalleled in the world nuclear experience; other stations do not have similarly well-organized annual competitions. As a yardstick against to measure these artistic endeavors, I also examine drawings, magazine covers, and other visual sources, for example, the journal Tekhnika-Molodezhi (Technology - to youth!) over a 40-year period since the dawn of the nuclear age. To compliment these visual sources, I conducted interviews with officials, press representatives and scientists connected with the nuclear industry, some of whom speak with obvious pride about the success of the effort to engage the public - and children in particular - about the 
importance of nuclear power in Ukraine's future. Government documents provide a final nuance to analysis of the banalization of the atom.

Indeed, analysis of these sources within the broader context of public understandings of science and technology indicates that the notion of the "domestication" of the atom is a particularly appropriate way to describe the process of banalization of nuclear technologies in Ukraine. It captures the attempts of the nuclear promoters to tame negative emotions following a major disaster and its radiological, political and social fallout. It describes the imaginary effort to bring the atom back under control, to force it to serve the national community, to make it friendly, accessible and even, in a way, innocent and fun. To better understand the process of domestication of nuclear things in such arenas as children's art contests, we shall analyze the major themes and foci of the paintings in the context of the industry's response to a perceived need to engage the public over the safety and efficacy of nuclear power, and the evolution of the Ukrainian nuclear industry since the break-up of the USSR in 1991 and Ukrainian independence.

\section{From Soviet to Ukrainian nuclear industry}

When the Chernobyl disaster occurred in April 1986, ten reactors were operating and seven more were under construction on Ukrainian territory. The nuclear power stations were managed from Moscow by the Soviet Ministry of Energy, bypassing ministries at the republican level, and making control and safety issues of Soviet, not local importance. Not even Chernobyl slowed the Soviet authorities from moving toward the construction of six new reactors at $1,000 \mathrm{MW}$ each that came on line in Ukraine between 1986 and 1990. ${ }^{2}$

After the extent of the disaster was finally revealed to the general public in 1989 a broad independence movement developed in Ukraine with anti-nuclear and environmental dimensions. ${ }^{3}$ Many of its participants denounced Moscow's Russiancentered economic development policies that contributed to the environmental degradation of Ukraine. They saw the Chernobyl accident and nuclear power in general as one of the manifestations of Russian-Soviet colonialism. In response to this

2 World Nuclear Association, 2018.

3 Dawson, 1996. 
anti-nuclear sentiment the Ukraine parliament in August 1990 voted to adopt a moratorium on the construction and commissioning of new nuclear power units. ${ }^{4}$

When Ukraine gained its independence in 1991 upon the collapse of the USSR, it fell into economic crisis, including inflation and deep recession. The country's leaders determined the need to preserve nuclear power capacity and abandoned the moratorium. ${ }^{5}$ They did so in an atmosphere when, after the dissolution of the Soviet Union, the main public attitudes toward nuclear power had changed dramatically as jobs, energy production and heating became more important than environmental concerns and uncertainty about the risks of nuclear power. There was little public protest when in October 1993 the Parliament voted to overturn the 1990 moratorium and to keep the three remaining undamaged reactors at Chernobyl in operation in order to address projected power shortages for the winter of that year.

In this difficult political and economic situation, the Ukrainian government had to form its own nuclear agencies and ministries from scratch, each of which went through a series of reorganizations. Goskomatom (the State Committee of Ukraine for the Utilization of Nuclear Energy) was formed soon after Ukrainian independence. Energoatom, its utility partner that operates all fifteen Ukrainian reactors, was created in 1995. Goskomatom became a small Department of Nuclear Energy in the Ministry of Energy and Coal Industry. As for regulation, Ukraine's State Inspectorate for Supervision of Nuclear Safety was created only in 1992, and struggled to establish its independence from the industry; in 2018 it is called the State Nuclear Regulatory Inspectorate.

The interactions between the nuclear industry and the public have also evolved significantly since Ukrainian independence. On the eve of the repeal of the nuclear moratorium in 1993, such anti-nuclear activists as Greenpeace Ukraine, Zelenyi Svit and the Green Party publicized what they saw as the unacceptable return of the nation to pro-nuclear positions, but they had little impact. ${ }^{6}$ Quickly after the repeal, construction resumed at Khmelnytska, Zaporizhzhya and Rivne stations. In 1995 Ukraine and the G7 countries signed a Memorandum of Understanding to close the Chernobyl NPP in exchange for significant compensation, including the completion of the Khmelnytska and Rivne nuclear power plants (called "K2-R4"). Ukrainian and

\footnotetext{
${ }^{4}$ Supreme Rada of Ukraine, 1990.

5 Supreme Rada of Ukraine, 1993.

${ }^{6}$ Kasperski, 2017.
} 
International NGOs (the National Ecological Center of Ukraine, Bankwatch, and Ekoclub-Rivne among others) opposed financing for new reactors; Ukraine finally acceded to demands to close Chernobyl in 2000, but with local financing and bond issues, not G7 or EU funds. K2-R4 came on line in October 2004.

We may understand the children's drawings against the backdrop of this difficult effort to energize Ukraine's nuclear enterprise and secure independence in the post-Soviet world. Ukraine's national nuclear program is about energy independence, and its leaders believe, emancipation from its powerful eastern neighbor, Russia, to which Ukraine is tied as part of the Soviet legacy for its primary energy supply (mostly gas). However, Ukraine must rely on Russian technology for nuclear reactors themselves, and for a variety of nuclear services including nuclear fuel from Russia that it returns for reprocessing. After Russian annexation of Crimea Ukraine started to take decisive steps towards diversification of fuel and technology supply to the west. In 2016, Ukraine bought about a third of its fuel assemblies from Westinghouse. ${ }^{7}$

Public communication in the domain of the civilian nuclear technology has constituted an important vector of the political, institutional and technological transformations of the nation's nuclear industry over the three decades that followed the collapse of the USSR. Even if the anti-nuclear movement in Ukraine turned out to be short-lived, significant controversies among citizens over nuclear power in the years that preceded the collapse of the Soviet Union provoked genuine shock among Ukrainian - and many other Soviet - nuclear scientists and engineers. Journals, whether those for general public or professional reviews, debated actively how to understand and remediate public distrust. Some nuclear experts blamed the lack of scientific education among the public, and its vulnerability to the political manipulators who instrumentalized peoples' fears and emotions for their own political goals. Others, however, saw the origins of distrust in the atmosphere of secrecy typical of the Soviet management not only of the military uses of the atom, but of civilian nuclear projects. Secrecy extended to the large numbers of victims in a series of accidents, from the Kyshtym nuclear waste dump explosion of $1957^{8}$ to Chernobyl. ${ }^{9}$

\footnotetext{
7 UNIAN, 2016.

${ }^{8}$ Medvedev, 1979; Brown, 2012.

${ }^{9}$ Medvedev, 1999; Kuchinskaya, 2014.
} 


\section{Domesticating the Atom in the post-Nuclear Bomb Era}

Strong emotions about atomic power are not specific to post-Chernobyl Ukraine. Nuclear technology has had a very rich emotional history as an object of strong and conflicting feelings: fear and enthusiasm, hate and awe. This duality was in part linked to the distinction between military and peaceful applications of atom, international geopolitics and domestic consumer politics. It reflected what Michael Smith defined as "one of the inherent contradictions of impression management in the nuclear age" ${ }^{10}$ : government and industry publicists had both to maximize the impression of the country's might and destructive potential, and to characterize the atom as a fascinating, but mundane technology, closely connected to artifacts of everyday life.

The fact that nuclear technology has inspired strong and often negative emotions has been problematic for the nuclear industry. Yet it has also been used to promote nuclear power. Researchers have thoroughly analyzed the "nuclear fear" that was initially inspired by the strong destructive potential of the bomb and that impeded the development of nuclear energy. ${ }^{11}$ Yet this fear was part of what researchers coined the "atomic sublime," the perception of the atomic bomb as an aesthetic object, one that arouses a mixture of awe and terror. ${ }^{12}$ As such it was instrumentalized by nuclear promoters because it contributed to maximize national prestige, inspire patriotism and impress adversaries, and transformed terror into an organizing principle of nation's security policy and an element of new kind of social contract. ${ }^{13}$

The nuclear energy industry recognized early on the need to play down or even dissimulate this association between the atom and destruction with regard to citizens' concerns. Paul Boyer argues that the purpose of civilian nuclear technologies was to overcome the fear of nuclear weapons and make people comfortable with nuclear technologies generally. ${ }^{14}$ This resulted in the effort of the industry and the states promoting it to "domesticate" the atom, "reducing its mysterious powers to the palpable dimensions of daily life," a daily life that the promoters of nuclear

\footnotetext{
10 Smith, 1993, p. 231.

11 Weart, 1988.

12 Hales, 1991; Masco, 2004.

13 Masco, 2014.

14 Boyer, 1985, pp. 107-132.
} 
technologies promised to transform for the better. ${ }^{15}$ The efforts of industry and government to make the atom "peaceful" found response in such cultural settings and products as film, advertisements, cartoons, and museums. Woman and children were also important targets of new advertising campaigns in such cartoons as "Our friend the Atom, ${ }^{, 16}$ exhibitions, ${ }^{17}$ and popular science journals East and West - the US, France, England, the USSR, and elsewhere where domestication brought the atom from secrecy into daily life. ${ }^{18}$ This process of domestication had an impact in the international arena as well, where the US and USSR competed in the ideological sphere during the Cold War to convince their publics that the governments wanted "atoms for peace" applications, not to destroy the planet, while the other was warlike. $^{19}$

Efforts to domesticate the atom expanded to counter the growing anti-nuclear movement and public controversies surrounding nuclear energy programs in the 1970s. Focusing on France, Sezin Topçu ${ }^{20}$ notes that industry representatives seriously considered the need to "desacralize the nuclear theme," since anti-nuclear protests were seen as reaction to views of the atom as something exceptional and thus "exceptionally risky" as well. Communication professionals carried domestication further, insisting that the nuclear reactor was nothing more than a huge tea kettle.

In Russia, Ukraine and elsewhere in the USSR, nuclear specialists faced antinuclear protests in late 1980s both because of the Chernobyl disaster and the liberalization of the political regime. They found themselves struggling to understand and deal with citizen's concerns about nuclear power. These efforts may have served as a foundation for post-Soviet domestication of nuclear technologies. In 1990 an important survey of public opinion about nuclear power that focused on the residents around several nuclear power plants in the Soviet Union (in Ukraine they selected the Khmelnytska NPP) revealed a rather even split of the population in favor and against nuclear power (around 40\% in each case). ${ }^{21}$ Another opinion poll, ordered by the Soviet Ministry of Atomic Energy, included the population around Zaporizhzhya and South Ukraine stations, where up to $80 \%$ of residents in the $30 \mathrm{~km}$ zone around the

\footnotetext{
15 Smith, 1991, p. 244.

16 Disney, 1957.

17 Forgan, 2003.

18 Josephson, 1990.

${ }^{19}$ Krige, 2010; Schmid, 2011.

20 Topçu, 2013, pp. 199-200.

21 Tsentr obshchestvennoi informatsii, $1991 \mathrm{~b}$.
} 
NPPs were against their continued operation. ${ }^{22}$ To overcome the negative consequences of secrecy and distrust, increasing public awareness about past accidents, and so on, many experts proposed educational efforts with the public, for example through such newly-created professional nuclear organizations as the nuclear societies of Russia and Ukraine that set out to convince themselves and others in the nuclear enterprise of the urgent need to engage the public. ${ }^{23}$

For our story, a crucial step in public engagement was the creation of such new spaces as local information centers and exhibitions from $1990 .{ }^{24}$ Most of the Soviet nuclear stations had prototype public relations services. Those included normally a few people responsible to receive delegations from other republics and countries within the Soviet bloc, and representatives of Soviet government and scientific institutions. NPPs typically sponsored a newspaper through the local trade union or communist party committee of 2,000 to 3,000 copies for a city of 30,000 to 40,000 people (for example the weekly Energia, published by the Rivne Nuclear Power station since 1978). During the early 1990s these services were enlarged and consolidated into information centers, in part to deal with what they perceived as "radiophobia" and ignorance among the public, in part in keeping with greater openness generally in society, and in part because plant operators and scientists believed in the need to educate the public about the importance of nuclear energy for the nation's future. New newspapers were created at the stations where they did not exist (for example, the weekly Perspektiva at the Khmelnytska NPP from 1989, whose editor-in-chief, a long-term member of the Ukrainian Nuclear Society, Pavel Gusarov is still in charge in the late 2010s). Every NPP in Russia and Ukraine has its own information center, and Russia also has opened sixteen regional nuclear information centers to serve public relations - and domestication.

At the beginning of 1990 the new information units at NPPs typically produced short, dull press releases about the levels of radioactivity in the surrounding environment, important events at the plant, and occasionally provided educational material about nuclear power and radioactivity. Their important innovation in public relations was the organization of excursions to the station for the general public and, most importantly, children. While these first measures to create "openness" in the

\footnotetext{
22 Gedroits, 1991; Tsentr obshchestvennoi informatsii, 1991a

${ }^{23}$ Barbashev, 2015.

24 Romanov, 1990.
} 
post-Soviet era may appear rudimentary, they were meant to emphasize the break from the previous tradition of secrecy.

\section{Taming Nuclear Fears in post-Chernobyl Ukraine}

In the first decade after Ukraine gained independence in 1991 nuclear promoters lacked experience and funding to extend their seduction of the public beyond the simple measures described above; information centers, if not reactors, had shoestring budgets. But by the turn of the twenty-first century, the industry began to revitalize and introduced important improvements in nuclear communication. The rehabilitation and enlargement of existing information centers and creation of new ones together with the expansion of their activities was the most visible sign of these changes. For example, the long awaited completion of the unit 4 at the Rivne power plant was celebrated with the inauguration of a new information center that occupied a renovated movie theatre in Kuznetsovsk (renamed in 2016 as Varash). This new center hosted a large screening room, an exhibition dedicated to the station's history, featured two mock-ups of the reactors, and included a small museum of local history and culture (kraevedcheskii) that helped to offer a cultural foundation to the importance of nuclear power for Ukrainian nationhood and energy independence.

Information centers in Ukraine grew in numbers of staff and departments (although later on some centers had to cut their staff due to limited budgets). A number of them added or enlarged news services, newspapers, and TV studios. They created webpages with news about the station; current operating and safety data; visits of delegations; photo galleries; and station publications. They continued to sponsor weekly newspapers. More important, the information centers became more autonomous from the administration of the power stations and moved off restricted power station sites to become accessible to the public who no longer needed special permission to visit them. They screened documentaries and cartoons; arranged visits to nuclear technology exhibitions and museums; organized lectures, festivals and plays; and they sponsored competitions for children including drawing contests.

While the drawing contests have a national level, constant changes in the direction of the industry, new appointments in Energoatom, the organization that operates all Ukrainian NPPs, different communication teams coming to power, and funding shortfalls have meant the absence of common methods or approaches in the effort at public outreach; each new Energoatom official brings in a new PR chief with 
his or her own concerns. ${ }^{25}$ If the information centers expanded and acquired new buildings and exhibitions, much of this came from local initiatives and often without common communication strategies directed to the outside communities.

Yet the drawing contests that have helped to banalize the atom have expanded and matured. The Khmelnytska NPP actually organized its first drawing competitions already in the 1990s: We live near KhNPP, in 1995; Netyshin - the city of energy specialists, in 1996 and 1997; and We live in the city of energy specialists, in 1998 and 1999. The artistic contest was part of a larger educational and entertainment program on nuclear themes for school children that included a short scientific essays competition, young poets and young journalists contests, or a comedy-show contest called KVN ("club of the funny and inventive people"). ${ }^{26}$ These events cast nuclear technology in a new light compared to the Soviet period. The atom was no longer only the subject of awe and fear and appropriate only to serious and courageous adult men and women, as nuclear scientists were portrayed in the extremely popular and serious classic Soviet movie "Nine days of one year" (1961) by the well-known film maker Mikhail Romm. ${ }^{27}$ Now the atom was something much more fun and suitable for children education and entertainment.

The drawing contests became widespread in the 2000s when Energoatom began to coordinate them. Yet they are very much local initiatives that rely on the enthusiasm of local teachers and information center employees who were often teachers or worked in secondary education. They came to be celebrations of the surrounding communities whose lives revolved around NPPs. The contests indicate that one does not need to employ sophisticated technologies to popularize such complicated matters as nuclear power production among children: a paper and a set of crayons or paints suffice. Contests could be -and were- run by local personnel with little money. The low costs and simplicity may be a symptom of a not yet completely polished form of professionalized communication. But even if they appear to be local,

\footnotetext{
${ }^{25}$ For example, Ilona Zaets, the chief of the PR and communication at Energoatom in 2016, came into the office with its new president, Iurii Nedashkovskii, who was appointed in the early 2014 after the political crises in Ukraine in 2013 and 2014, and the flight of former Ukrainian President Yanukovich from office in February 2014.

${ }^{26} \mathrm{KVN}$ (Klub vesiolykh i nakhodchivykh - "Club of the Funny and Inventive People") is a wildly popular Soviet and later Russian comedy TV show that involves teams of university students that compete through funny sketches, prepared in advance or improvised. The programme existed between 1961 and 1972 on the Soviet television, was then forbidden, and reappeared with Gorbachev after 1986.

${ }^{27}$ The film portrayed a nuclear scientist, his colleagues and friends, his important but risky - to himself - experiments in nuclear fusion, his sentimental life and professional devotion.
} 
and sometimes almost a bit "naïve", the drawings circulated widely. As far as I know, the drawings are usually not restituted to children, but are preserved in the archives of the local information centers, sometimes both in paper and in electronic form. They appear on the walls of information centers, on official web-pages and in social media, in printed publications, and are even offered as presents to foreign guests of Energoatom and local centers.

Regarding content, even if these contests aim at encouraging originality and creativity, they contribute to standardize visual representations of nuclear power. From year to year the drawings repeat some of the same themes. Children even copy the drawings from previous years they find on the internet or displayed in the information centers. For example, the picture of a woman in a traditional national costume and a crown of flowers against the background of Rivne Nuclear Power station cooling towers won a prize in $2013 .{ }^{28}$ Three similar pictures highly evocative of the 2013 painting were sent to the drawing contest organized by Khmelnytska station in 2016.

This can be explained because the conditions of production of these drawings can vary, but very often, especially in the case of the local winners (there are usually a dozen or more winners in different categories), they are produced in local art-schools or at art lessons in the regular schools. That is, most of the drawings are produced in the framework of institutionalized interventions and are not the pure results of children spontaneous artistic imagination. Some members of the jury are often art teachers as well. Apparently, even parents participate in the process.

\section{Making nuclear plants accessible, familiar, "natural"}

A significant element in Ukrainian children's drawings on nuclear themes is the very visibility of nuclear power installations that they represent. This visibility translates the attempts of the Ukrainian nuclear industry to stage itself as more open, accessible and thus very different from the Soviet nuclear industry, criticized for its secrecy and closedness. This remains, according to public relations officers of Energoatom whom I interviewed, the main purpose of nuclear information effort in the industry today

${ }^{28}$ Rivne Nuclear Power Plant, 2013a. 
The importance of this visibility is better appreciated if compared to the restricted visuality of nuclear power during the Soviet period, by which I mean the fact that people understood the presence of nuclear technologies, both civilian and military, but rarely encountered public representations of them in photographs, paintings, drawings, and so on. Even though a thorough analysis of the Soviet visual representations of the atom is still to be conducted, the existing literature and the exploration of some examples of the Soviet media for the popularization of technology among children and young people indicates an intriguing paradox about Soviet "nuclear culture". On the one hand, nuclear and space technology were culturally and politically significant during Soviet times. Achievements in these areas were actively promoted in the media, in exhibitions, and in the scientific popular literature that exploded in popularity in the 1950s and 1960s. They served to reinforce constructivist visions of communism as scientifically and technologically advanced utopia. $^{29}$

Yet a closer look at these materials indicate a peculiar characteristic of Soviet nuclear culture, its restricted visuality: the relative absence of visual representations of atomic power in comparison with the abundant pictures and drawings of other technologies crucial for imagining Soviet technological might, above all, space technologies. This is the case, for example, of drawings and paintings in popular art contests organized by the main Soviet scientific-popular monthly, Tekhnika molodezhi, founded in $1933 .{ }^{30}$ From the late 1960 s the magazine conducted artistic contests on such futuristic themes such as "The World of Tomorrow ","The World of 2000", "Siberia tomorrow" and "Time, Space, Man". Both professional and amateur artists submitted their pictures and drawings. ${ }^{31}$ The contest "Time, Space, Man" that first took place between 1977 and 1980, and then periodically until the breakup of the USSR, had a specific section for children under 17 years old called "Children draw the future." ${ }^{32}$ During the first three years of the contest, more than a thousand works were received from all over the USSR and from other socialist countries. Judging from the roughly 200 that were published in Tekhnika-molodezhi, nuclear themes

\footnotetext{
29 Josephson, 1990; Schmid, 2012.

${ }^{30}$ This analysis is based on the reading of forty years of Tekhnika-molodezhi from the 1950s to the collapse of the USSR in 1991.

31 Komissarov, 2012.

32 N. A., 1987.
} 
were not part of the visions of technological future. ${ }^{33}$ The images related to space, like the drawings of three Ukrainian children published by the journal in 1979, were the most common. ${ }^{34}$

The artwork images that adorned journal covers also point to the restricted visuality of nuclear power. From 1950s through 1980s Tekhnika-molodezhi covers based on paintings and drawings focused on space, cosmonauts, dams, rockets, hydro and thermal power stations, future cities, ships, submarines, automobiles, planes, and many other real and imagined engines. Only a few of the almost 500 covers of that period were specifically dedicated to nuclear energy, most of them during the $1950 \mathrm{~s}^{35}$ During the 1960 s and the 1970 s only two covers were dedicated to nuclear energy, and no nuclear-themed covers were published in 1980s. On the contrary, over a hundred covers featured space-related themes between the 1950s and 1980s.

The relative lack of visual representations from the nuclear sphere reflects the highly political nature of the atom. Indeed, the control of the production and circulation of images was closely connected to policies of secrecy, especially in the first decades after World War II when the military requirements of the nuclear bomb prevailed. ${ }^{36}$ Secrecy restrictions surrounding nuclear power narrowed the options for visual communication. As for the civilian atom, nuclear power plants hardly looked to general audiences any different from other Soviet industrial installations, as seen in the first NPP depictions in Tekhnika - molodezhi. The only visual depiction of the atom found regularly in the popular media was the so-called "planetary" model of the atom proposed by Nils Bohr in 1913: a positively-charged nucleus and negativelycharged electrons that orbit it, similar to the planets orbiting the Sun. The classic "planetary" representation of the atom was often to be found in Soviet popular media. It was ubiquitous as one of many visual symbols of Soviet technological and scientific progress, if rarely used as a main focus of a magazine cover alone. ${ }^{37}$ Perhaps the symbol was popular because it is simple and it fit well with Soviet space imagery. In

\footnotetext{
33 N. A., 1980.

34 Klenov, 1979.

${ }^{35}$ For example, the cover of the November 1955 issue represented the world first nuclear power station in Obninsk, launched in 1954, while that of November 1957 pictured an unidentified potential power plant. The cover of October 1958 was dedicated to a fusion reactor.

36 Bigg, 2015; Hales, 1991; Forgan, 2003.

${ }^{37}$ The only exception was the rare "atomic" cover of Tekhnika-molodezhi in September 1972, the only cover dedicated to nuclear power during the 1970s and the 1980s when the vast majority of Soviet nuclear power reactors were built, that features a woman holding the shining "atom". This cover was a reproduction of an artistic photograph sent to an international photo competition, "Technical-Scientific Revolution in the focus," co-organized by the journal.
} 
some artistic works on futuristic and technological themes reproduced in popular journals this symbol of the atom and depictions of space could be easily confounded. $^{38}$

Decades later, the "planetary" symbol of the atom is ubiquitous in Ukrainian children's drawings pictures on nuclear themes. But a distinguishing feature is that those drawings make nuclear installations themselves visible: reactor buildings, chimneys, cooling towers. Sometimes these nuclear installations occupy the central place on the picture, and sometimes they are depicted as part of a larger urban, natural or even cosmic landscape. Yet they are easily recognizable as particular units of the concrete power stations: blue blocks with thin white and red-striped chimneys of the Khmelnytska station (Figure 1), big grey cooling towers with white and red-striped belts of the Rivne NPP (Figure 2), ${ }^{39}$ or the red brick towers and white crowns of the South Ukraine NPP. ${ }^{40}$ The fact that NPPs are easily recognized even by children makes them appear symbolically accessible and familiar.

Other details of the drawings reinforce the friendly and familiar character of nuclear machines: children play peacefully against the backdrop of atomic power stations, the sun shines, flowers are blooming and the cooling towers are smiling (Figure 2). ${ }^{41}$ The drawings are thus an expression of the fact that nuclear power plants are in a way a "natural" part of the local children's life. Children see them almost every day, many of their parents work there, they are conscious that the presence of nuclear power stations makes their town or village quite different from others. In fact, ever since the Soviet period, nuclear plants are not merely big enterprises that happened to be situated in some particular town, but the towns themselves were most often built for the plant workers and their families, and the NPP owned and in many cases still does own all of the social and cultural infrastructure in these cities: daycare, schools, cultural institutions, sport facilities, communications, auxiliary businesses, and so on. Nuclear installations are thus indeed indistinguishable from the hometown,

\footnotetext{
${ }^{38}$ In his analysis of the promotion of the nuclear and space technology during 1964 World's Fair Michael Smith (1993: 229-30) notes also that the connections between space and nuclear achievements where often underscored, and the visual similarity between the planetary models and the diagrams of the solar system was deemed significant by the science and technology advertisers. On the connections between the two technologies in science popularization promotion in Soviet Union see Josephson (1990).

${ }^{39}$ See also Rivne Nuclear Power Plant, 2013a and 2018a.

40 South Ukraine Nuclear Power Plant, 2011 and 2013.

${ }^{41}$ See also Rivne Nuclear Power Plant, 2018a; South Ukraine Nuclear Power Plant, 2011 and 2013.
} 
community, family life and childhood, and as such objects of attachment, pride and even love.

Finally, bucolic nature that rarely appeared in Soviet depictions of the atom ${ }^{42}$ serves frequently to embrace the atom in the drawings of nuclear installations in Ukraine. Children no doubt draw inspiration from the official nuclear power plant websites that abound in photographs of the reactors buildings and cooling towers surrounded by trees, flowers, water, birds (Figure 1). ${ }^{43}$ The public photo albums, calendars and other materials from nuclear enterprises are intended to show this "oneness" with nature. ${ }^{44}$ This is not far from the truth, since nuclear power plants are "objectively" in nature. They require a huge site in the first place, secure from the outside with fences to prevent encroachment by the public or worse yet terrorists, and are near to a massive body of water to supply cooling water. To emphasize "oneness" with nature, industry strives to show that reactors belong in nature or perhaps even are natural objects. This reflects a kind of post-Chernobyl reassurance and selfreassurance that reactors are safe and simple, that children and mothers are comfortable with them, and that they are commensurate with nature. Nature itself is often portrayed as a mother figure that protects Ukrainians from possible negative technological impact.

\section{Defining the public-technology relationship: children as an ideal public}

A drawing contest should also be seen as an instrument to define the relationship between the public and the industry, and to project an ideal representation of how the citizens should engage technology. In these contests children are excited about nuclear technology in the way that all people should be excited by it, and they resemble scientists in their wonder of what is possible in the nuclear world. In her study of the history of science popularization for children in the United States, Rebecca Onion points out that "the trope comparing children with scientists and scientists with children has generally been complimentary to both groups." 45

\footnotetext{
${ }^{42}$ I have looked at several Soviet-era photo albums of nuclear installations and virtually none of them employ "nature" as a significant backdrop to the NPPs. These are cold machines rather than pastoral ones. See, for example, Knorre, 1977 and Kalinin, 1980. Such albums are themselves rare in distinction with the surfeit of publications in the last 20 years.

${ }^{43}$ See also Rivne Nuclear Power Plant, 2018a.

${ }^{44}$ See, for example, the photo galleries at the official webpages of Rivne Nuclear Power Plant, 2018b, and South Ukraine Nuclear Power Plant, 2018, or recent printed photoalbums: Khmelnytska Nuclear Power Plant, 2012; Rivne Nuclear Power Plant, 2013b.

45 Onion, 2016, pp. $4,7$.
} 
Similarly, one can say that juxtaposition of children and nuclear power through the drawing competitions in Ukraine can be seen as a potent site of the nuclear technology popularization, one that has helped to project positive representations of the atom, Ukrainian children and the national future in one place, and to shape the public attitudes towards civilian nuclear technologies.

Several aspects of the engagement of children with nuclear power in Ukraine are important from this point of view. First of all, children appear as the incarnation of an ideal public, at least from the point of view of the industry and specialists. After the powerful anti-nuclear protests of the late 1980s and early 1990s, nuclear experts struggled to restore the prestige of nuclear science and technology in post-Soviet Ukraine. Like the partisans of the "public understanding of science" approach in the 1980s in western countries, they believed that to overcome people's fears they needed to produce a better-informed public. The representatives of the nuclear sphere and other modern technologies saw the lack of public trust as the result of an understanding "deficit" had to be addressed through dissemination of scientific knowledge translated into a simple language for lay people. ${ }^{46}$ This deficit model of the understanding of science and technology assumed a clear hierarchy between the experts, scientists, engineers, on one side, and lay people, on the other. The first are the only holders of the true knowledge, whereas the others have to make an effort to understand the general principles of science and technology, their unquestioned benefits, and to support their development. A child (or at least an ideal-type child as imagined in the popularization of science and technology) is arguably what every member of the public should be according to this model: a passionate, naive, enthusiastic pupil, willing to listen and to understand the knowledgeable and authoritative adult experts. In a way, as Onion $^{47}$ demonstrates in her analysis, this imaginary child is often better equipped to understand science because of his or her "innocence" and because his or her thoughts were not clouded by adult misconceptions and fears.

\footnotetext{
${ }^{46}$ See, for example the report on the "public understanding of science," published by British Royal Society in 1985 that identified five different types of publics with regard to their needs in science education and urged industries and scientists to "learn how to explain science simply, without jargon and without being condescending," The Royal Society, 1985, pp. 6-7. For an analysis of the "public understanding" approach that criticises the assumption that people's distrust of science and technology is related to some "deficit" in knowledge or understanding, see Bucchi \& Neresini, 2008; Rodríguez, Rué \& López, 2013. For a more "interpretative" approach to the "public understanding of science", see Wynne, 1992, 1995; Michael, 1998, 2002.

47 Onion, 2016.
} 
Another trope involved in the engagement of children with the nuclear sphere is the one that presents children as the "ambassadors" educating their parents and sharing with them their fascination with science and technology. It may be impossible to measure whether and to what extent children influence their parents. ${ }^{48}$ Yet already in the early 1990s nuclear specialists in professional societies in Ukraine advanced the idea of working with children's drawings to engage both younger and older audiences, and the information centers have embraced them fully. They see children as potential future young cadres for nuclear industry and as easier to engage than adults. ${ }^{49}$ The necessity to engage young people - in the hopes that some of them might enter the industry - grew in the 1990s and 2000s as the industry suffered from the loss of personnel due to brain drain, primarily to Russia's more dynamic nuclear industry and higher salaries, and significant budgetary and other problems in higher education that led to fewer young specialists in training. Children are thus tomorrow's adults, cadres of the nuclear industry or citizens supporting its development. Children also symbolize the future of the nation, a future to which all Ukrainians should aspire, too, the one closely linked with technological prowess and dynamic development.

\section{Post-Soviet national nuclear imaginary: from Soviet to Ukrainian visions} of nuclear power

The last dimension of the domestication of the atom in contemporary Ukraine is the "nationalization" of atom -- its inscription into complex representations about the Ukrainian nation, its past, present, traditions and modernity. The nuclear enterprise in post-Soviet Ukraine and elsewhere has been influenced by what Sheila Jasanoff and Sang-Hyun Kim called "sociotechnical imaginaries," that is "collectively imagined forms of social life and social order reflected in the design and fulfillment of nation-specific scientific and/or technological projects. Imaginaries, in this sense, at once describe attainable futures and prescribe futures that states believe ought to be attained." 50

Nuclear and other technologies require massive state investments and represent a country's commitment on the very long term. To justify these investments and commitments, and to mobilize necessary human and financial resources, nuclear

\footnotetext{
48 Onion, 2016.

49 Barbashev, 2015.

50 Jasanoff \& Kim, 2009, p. 120.
} 
promoters often rely on elaborate representations of the benefits of the atom and its importance for the country. Although the connection between the large-scale technological projects and national identity is not specific to Ukrainian context ${ }^{51}$, this connection was particularly strong in the former Soviet republic. Indeed, the nuclear program in the post-Chernobyl decades took place during intensive period of nationbuilding that followed the Soviet collapse. During this period, the country's elites looked for ways to define national identity and to distance it from the Soviet legacy. Still, the Ukrainian nuclear program was a decisively Soviet enterprise: Soviet reactor technologies managed by Soviet institutions and specialists from Moscow.

For decades, Soviet nuclear research and industry achievements were promoted as proof of Soviet technical, political and economic grandeur ${ }^{52}$, a nuclear imaginary that Paul Josephson ${ }^{53}$ described as "atomic-powered communism" based on utopian visions that reappeared after the death of Stalin in 1953. These visions were those of an efficient socialist world with a high-tech industry, producing vast quantities of electric energy, much of it by nuclear power plants, that freed workers from tedious manual work. They were connected to the very ambitious electrification plan adopted in 1920 by the State Commission for Electrification of Russia led by Vladimir Lenin (known by its Russian acronym GOELRO). ${ }^{54}$

A clear illustration of the important cultural role of Soviet nuclear imaginary was the Pavilion for Atomic Energy at the Exhibition of the Achievements of the Socialist Economy (VDNKh in its Soviet acronym). The pavilion was inaugurated in 1956 when VDNKh reopened after the War. The pavilion - among many pavilions of achievement - was a citadel of Stalinist cultural iconography. It employed popular science, films, and exhibits to encourage utopian optimism of a coming, bright communist future. The goal was for visitors to be educated, to deepen their understandings, to gain scientific literacy that they might spread, and to facilitate acceleration of modern science into the economy, all the while becoming proud loyal supporters of communism. The Atomic Energy Pavilion operated a $100 \mathrm{~kW}$ reactor

\footnotetext{
${ }^{51}$ For the analysis of the connections between nation-building and nuclear technologies see, for example studies by Hecht, 2009; Jasanoff \& Kim, 2009; Leslie, 2015; Kasperski, 2015.

${ }^{52}$ See Kurchatov, 1956. The journals Tekhnika-Molodezhi, Nauka i Zhizn' and others in the 1950s published dozens of articles on nuclear enthusiasm. Also see Josephson, 1990, 1996 and Schmid, 2006, 2012.

53 Josephson, 1996.

${ }^{54}$ The futurist political vision on which this project rests was summarised by Lenin in his famous formula: "Communism equals the Soviet power plus the electrification of the whole country". On GOELRO and its origins see Coopersmith, 1992.
} 
from 1959-62. The Pavilion closed in 1989, a fact that is perhaps symbolic of the decline in positive nuclear messages. ${ }^{55}$

After Chernobyl and the collapse of the Soviet Union, engineers and state officials in independent Ukraine had to redefine nuclear technology both as positive and as something no longer Soviet, but Ukrainian. There have been competing definitions of what is the Ukrainian nation, definitions that reflected ambiguities in attitudes toward Russia. Many individuals emphasized a shared cultural heritage between Ukrainians and Russians, while others focused on differences with Russians, on Ukrainian ethnicity and language, and a pro-Western orientation. ${ }^{56}$ In this context, nuclear technology might be seen as a shared heritage with Russia. More frequently, a stable and powerful nuclear enterprise has been promoted as an important precondition for the country's national prosperity and independence from its Eastern neighbor - and from its gas and oil. Nuclear officials have pointed out that Ukrainian NPPs produce more than half of the country's electricity and that nuclear energy was thus an instrument of emancipation from Russia, even if Ukraine relies heavily on Russia for nuclear fuel, reprocessing and other nuclear technologies.

How were these nationalized visions of nuclear power reflected in children's drawings? At least some of the drawings submitted to contests focused on themes of shared pasts. For example, a 2007 drawing selected to represent Ukraine in an annual competition, at the time co-sponsored by Energoatom and Russian nuclear fuel producer, TVEL, emphasized cooperation between the two nations. It featured two blocks under construction at Khmelnitsky NPP, initially planned to be finished by a Russian company, with two hands shaking and the flags of the two countries unfurled.

More frequently, however, and especially so since the beginning of the political and military conflict between the two counties in Eastern Ukraine and Crimea, nuclear energy appears uniquely connected to the Ukrainian nation's drive to be independent from Russia. The visual celebration of the Ukrainian nation and its traditions is probably the most striking difference between Soviet and contemporary Russian visual representations of nuclear energy and post-Soviet Ukrainian ones. Whereas the Soviet atom was associated with a glorious technological future and modernity, Ukrainian nuclear imaginary in these drawings involves an attempt to

\footnotetext{
55 Schmid, 2006.

56 Goujon, 2009; Shulman, 2004; Kuzio \& D’Anieri, 2002.
} 
reconcile nuclear modernity with national tradition. This is the most visible in abundant elements of folk art, national and religious iconography.

Folk art has inspired both Ukrainian avant-garde artists at the beginning of twentieth century and artists in the post-Soviet period. ${ }^{57}$ It has become an important part of art and education curricula in general as part of nation-building and policies of de-Sovietization. ${ }^{58}$ Many of the children's works on nuclear themes draw heavily on folk art using strong colors, naïve style, and rich ornamentation. The drawings often feature such objects of the traditional decorative art as kilims (ornamented woven rugs), rushnyks (embroidered or woven towels), painted Easter eggs, and folk instruments. $^{59}$

The drawings abound in depictions of men, women and children in folk dress (Figure 1). ${ }^{60}$ Traditional costumes indeed played an important role as a tool of shaping an "authentic" Ukrainian nation after the Soviet break-up. During this period traditional women's clothing, especially embroidered fabrics, have been embraced with 'new meanings of nationalism, cultural identity and pride' and cemented in such public displays as musical ensembles, choral groups and folk dance troupes. ${ }^{61}$ Female figures in national costumes and in traditional crowns of flowers are one of the most popular elements of children drawings on nuclear themes (Figure 1). ${ }^{62}$

Another national symbol, the Cossacks, has recently become a more prominent part of the children drawings, which seem to indicate the dramatic overtones that the feeling of national belonging has acquired since Russia annexed Crimea and engaged in a "hybrid war" in East of Ukraine in 2014. The Cossacks, East Slavic peoples of self-governing, military hosts or groups who since the fifteenth and sixteenth centuries lived in river basins in what are today's southern Ukraine and Russia, and over whom there are many confusing and confused debates about history and legacy, have become important in independent Ukraine as a symbol of masculinity, religious revival, culture (including icon painting), and nationality. ${ }^{63}$ In

\footnotetext{
57 Shkandrij, 2009.

58 Wanner, 1998.

${ }^{59}$ Rivne Nuclear Power Plant, 2018a.

${ }^{60}$ See also Rivne Nuclear Power Plant, 2018a; South Ukraine Nuclear Power Plant, 2011.

61 Van Orman, 2013.

62 See also Rivne Nuclear Power Plant, 2013a and 2018a; South Ukraine Nuclear Power Plant, 2013.

${ }^{63}$ It should be also noted that for Russia, the Don Cossacks represent the Russian imperial vision and have contributed to separatism in Eastern Ukraine even if the Donbas is integral to contemporary Ukrainian identity. On the historical and symbolic role of the Cossacks, see Wilson, 1995; Plokhii, 2006; Bureychak \& Petrenko, 2015; Sysyn, 1991.
} 
spring 2015, Energoatom organized precisely an artistic competition in the nation's nuclear cities related to the proxy war with Russian under the title "Glorious Heirs of the Cossacks". This contest suggested that both nuclear energy and the glorious national tradition contributed to the strength and resilience so crucial in the present very difficult period for Ukraine. A teenager from Varash, the town near the Rivne NPP, won the first prize in the contest with a cartoon telling the story of a boy whose father leaves home to go to war and defend his Motherland. ${ }^{64}$ Drawings have thus cemented feelings of nation, tradition, and modernity in the nuclear sphere.

\section{Conclusion: Chernobyl Haunting}

And what of the Chernobyl disaster? Do we find its traces in the drawings of children who live just a few hundred kilometers from the accident site? How do nuclear risks figure in these pictures? The drawing contests seem to encourage only positive visions of the nuclear power, and children must know the rules of the game in order to advance in the competition. Among the several hundred drawings sent to the competitions that I have examined, including assisting the jury of such competitions in Netishyn and Varash in spring 2016, I still found a handful that one might suspect of suggesting criticism of nuclear power. Some of them featured such alternatives to nuclear power as wind energy, and others reminded the audience that the atom can be destructive as well as creative. And, I sensed, these pictures tended to be quickly "selected out" as ones that, some judges asserted, were "too dark" or "not standing a chance to win on a national level."

It is also the case that children know something about Chernobyl, but they try to insert it in the framework of their own familiar world in order to domesticate it in a way. One striking example is "Nuclear family of Ukraine" which won the first prize in the age group of 7 to 9 year old at the competition organized by the South Ukraine NPP information center in December 2013. The drawing features a "mother-Ukraine" with five "children", the five Ukrainian nuclear stations including a "handicapped child" - the Chernobyl NPP. ${ }^{65}$ The Chernobyl disaster appears to be here as a kind of family trauma, a trauma that one remembers in the intimacy of a circle of family and friends, but which is not always appropriate to exhibit in public nor to instrumentalize it for political goals. Another example, "Remember the Past, Think of the Future",

\footnotetext{
${ }^{64}$ Energoatom, 2016. The cartoon can be seen on YouTube, Raduk, 2015.

65 South Ukraine Nuclear Power Plant, 2013.
} 
highlights a two-sided woman's face; it received honorable mention during in the 2016 contest in Netishyn (the Khmelnytska NPP) around the time of the $30^{\text {th }}$ anniversary of the Chernobyl disaster (Figure 3). Its meaning is that Ukrainian children know about the past, about Chernobyl, but they are encouraged to overcome their fears and to remain confident about national future. "Mother nature" and "Mother nation" figures that figure in these drawings convey the message that the nation accepts technology, is strengthened by it and is protected from its negative impact. ${ }^{66}$ Even if the negative consequences of Chernobyl continue to haunt Ukraine, the country, those pictures show, cannot do without nuclear energy: nuclear energy is a predicate for national survival.

What we see in these pictures could be a reflection of what some researchers have called the "distance of fear" that refers to the fact that the closer you live to a potentially dangerous industrial site, the less afraid you are. ${ }^{67}$ In this regard children's artistic contests appears to be an instrument for reducing that imaginary distance, bringing the atom symbolically closer to peoples homes, domesticating and banalising it. More generally, the drawings show us that nuclear and other technologies are part of very different social "worlds" or "arenas" that coexist in the same society. These worlds have different types of order, a hierarchy of values that are based on different principles of reasoning and dictating different logics of "justification." ${ }^{68}$ The argumentation based on risk, its relation to benefits, or the need for citizen's oversight over a dangerous industry is often not relevant to most people who have lived in nuclear towns their entire lives - and this holds for many places in the world.

Nor does it make sense to their children. The children express this in their drawings by depicting a world of belonging and attachment, loyalty and pride, nature and nation. It is important to recognize that nuclear energy can be an important part of people's lives and the way a nation imagines its own past, present and future. It is also crucial that the politics of nuclear technology allow other such arenas as the public, civic one with contentious debate over risks and benefits of the atom, to contribute to the definition of technological development. Most of the children's drawings help to domesticate the atom and to bring it into a world where risks are invisible and themselves have been banalised. It remains a serious question if this banalization of

\footnotetext{
66 Rivne Nuclear Power Plant, 2013a.

67 Storm, 2014, pp. 47-73.

68 Boltanski \& Thévenot, 2006.
} 
the atom can contribute anything to a discussion of the future of nuclear energy in Ukraine.

\section{References}

Barbashev, S. (2015, October). Interview with Serguey Barbashev, co-founder and former secretary of the Ukrainian Nuclear Society. Odessa, Ukraine.

Bigg, C. \& Hennig, J. (2009). Atombilder: Ikonografie des Atoms in Wissenschaft und Öffentlichkeit des 20. Jahrhunderts. Göttingen, Germany: Wallstein Verlag.

Bigg, C. (2015). Le siècle de l'atome en images. In C. Bonneuil \& D. Pestre (Eds.), Histoire des sciences et des savoirs, vol. 3: Le siècle des technosciences (pp. 167-185). Paris, France: Seuil.

Boltanski, L. \& Thévenot, L. (2006). On Justification: The Economies of Worth. Princeton, NJ: Princeton University Press. (French original in 1991).

Boyer, P. (1985). By the bomb's early light: American thought and culture at the dawn of the atomic age. New York, NY: Pantheon.

Brown, K. (2012). Plutopia: Nuclear Families, Atomic Cities, and the Great Soviet and American Plutonium Disasters. Oxford, England: Oxford University Press.

Bureychak, T. \& Petrenko, O. (2015). Heroic Masculinity in Post-Soviet Ukraine: Cossacks, UPA and 'Svoboda.' East/West: Journal of Ukrainian Studies 2(2), 3-27.

Bucchi, M. \& Neresini, F. (2008). Science and public participation. In E. Hackett et alii (Eds.), Handbook of Science and Technology Studies - Third Edition (pp. 449-473). Cambridge, MA: MIT press.

Coopersmith, J. (1992). The Electrification of Russia, 1880-1926. Ithaca, NY: Cornell University Press.

Dawson, J. (1996). Eco-Nationalism: Anti-Nuclear Activism and National Identity in Russia, Lithuania, and Ukraine. Durham, NC: Duke University Press.

Energoatom. (2016, February 11). RAES vidkryvaie estafetu patriotychnykh vystavok " $\mathrm{z}$ nadiieiu do peremohy." Retrieved from http://www.energoatom.kiev.ua/ua/actvts/social/news/44850raes_otkryvaet_estafetu_patrioticheskih_vistavok_z_nadyu_do_peremogi/.

Forgan, S. (2003). Atoms in Wonderland. History and Technology, 19(3), 177-196.

Gedroits, B. A. (1991). AES: 'za' i 'protiv': Informatsionnoe pis'mo po rezul'tatam sotsiologicheskogo issledovaniia po izucheniiu obshchestvennogo mneniia naseleniia regiona AES $\mathrm{k}$ atomnoi energetike. Informatsionnyi biulleten' Tsentra obshchestvennoi informatsii po atomnoi energii, 8, 67-69.

Goujon, A. (2009). Révolutions politiques et identitaires en Ukraine et en Biélorussie (1988-2008). Paris, France: Belin.

Hales, P. B. (1991). The Atomic Sublime. American Studies, 32(1), 5-31.

Hecht, G. (2009). The Radiance of France: Nuclear Power and National Identity after World War II. Cambridge, MA: MIT Press.

Jasanoff, S. \& Kim, S.-H. (2009). Containing the Atom: Sociotechnical Imaginaries and Nuclear Power in the United States and South Korea. Minerva, 47(2), 119146.

Josephson, P. (1990). Rockets, Reactors and Soviet Culture. In L. Graham (Ed.), Science and the Soviet Social Order (168-191). Cambridge, MA: Harvard University Press.

Josephson, P. (1996). Nuclear Culture in the USSR. Slavic Review, 55(2), 297-324. 
Josephson, P. (2005). Red Atom: Russia's Nuclear Power Program from Stalin to Today. Pittsburgh, PE: University of Pittsburgh Press.

Kalinin, V.F. (1980). Atom neischerpaem. Moscow, Russia: Atomizdat.

Kasperski, T. (2015). Nuclear Dreams and Realities in Contemporary Russia and Ukraine. History and Technology, 31(1), 55-80.

Kasperski, T. (2017). Ukraine Short Country Report. HoNESt : History of Nuclear Energy and Society. Barcelona, Spain: Pompeu Fabra University. Retrieved from http://honest2020.eu/sites/default/files/deliverables_24/UA.pdf

Khmelnytska Nuclear Power Plant. (2012). Khmel'nyts'ka AES: Harmoniia iz Dovkilliam. Rivne, Ukraine: AES-PRESA.

Klenov, V. (1979). Deti zemli - deti kosmosa. Tekhnika Molodezhi, 7, 6-9.

Knorre, E. S. (1977). Atom sluzhit sotsialismu. Moscow, Russia: Atomizdat.

Komissarov, V.V. (2012). Razvitiie kinofantastiki i fantasticheskoï zhivopisi v kontekste istorii sovetskoï intelligentsia. Izvestiia vysshyh uchebnykh zavedeniï, $3(1), 5-10$.

Krige, J. (2010). Techno-Utopian Dreams, Techno-Political Realities: The Education of Desire for the Peaceful Atom. In M. D. Gordin, H. Tilley, G. Prakash (Eds.), Utopia/Dystopia. Conditions of Historical Possibility (pp. 151-175). Princeton, NJ: Princeton University Press.

Kuchinskaya, O. (2014). The Politics of Invisibility: Public Knowledge about Radiation Health effects after Chernobyl. Cambridge, MA: MIT Press.

Kurchatov, I.V. (1956). Nekotorye Voprosy Razvitiia Atomnoi Energetiki v SSSR. Atomnaia Energiia, 3, 5-10.

Kuzio, T. \& D'Anieri, P. (Eds.). (2002). Dilemmas of State-led Nation-building in Ukraine. Westport, CT: Praeger.

Leslie, S. W. (2015). Atomic structures: the architecture of nuclear nationalism in India and Pakistan. History and Technology, 31(3), 220-242.

Masco, J. (2004). Nuclear Technoaesthetics: Sensory Politics from Trinity to the Virtual Bomb in Los Alamos. American Ethnologist, 31(3), 1-25.

Masco, J. (2014). The Theater of Operations: National Security Affect from the Cold War to the War on Terror. Durham, NC: Duke University Press.

Medvedev, Z. A. (1979). Nuclear Disaster in the Urals. London, England: Angus \& Robertson.

Medvedev, Z. A. (1999). The Legacy of Chernobyl. New York, NY, London, England: Norton.

Michael, M. (1998). Between citizen and consumer: multiplying the meanings of the "public understanding of science." Public Understanding of Science, 7(4), 313327.

Michael, M. (2002). Comprehension, Apprehension, Prehension: Heterogeneity and the Public Understanding of Science. Science, Technology \& Human Values, 27, 357-378.

N.A. (1987). Doroga v budushchee. Tekhnika Molodezhi, 1, 21.

N.A. (1980). Itogi Konkursa. Tekhnika Molodezhi, 12, 25.

Onion, R. (2016). Innocent Experiments: Childhood and the Culture of Popular Science in the United States. Chapel Hill, NC: University of North Carolina Press.

Plokhii, S. (2006). (Mis)understanding the Cossack icon. Harvard Ukrainian Studies, 28(1-4), 591-602.

Raduk, A. (2015, April 17). Nashchadky kozakiv. Youtube. Retrieved from https://www.youtube.com/watch?time continue $=12 \& \mathrm{v}=79 \mathrm{NzZ0CDTgM}$. 
Rivne Nuclear Power Plant. (2013a, April 24). "Atomna vesna" peremogla. Retrieved from https://www.rnpp.rv.ua/\%C2\%ABatomnaya-vesna $\% \mathrm{C} 2 \% \mathrm{BB}$-pobedilaua.html.

Rivne Nuclear Power Plant. (2013b). Rivnens'ka AES: Perlyna kraiu, Kuznetsovsk: Upravlinnia informatsii ta zv'iazkiv z gromads'kistiu VP Rivnens'ka AES.

Rivne Nuclear Power Plant. (2018a). Fotogalereia: AES ochyma detei. Retrieved from https://www.rnpp.rv.ua/gallery/?galAlbum=11.

Rivne Nuclear Power Plant. (2018b). Fotogalereia: Prommaidanchyk. Retrieved from https://www.rnpp.rv.ua/gallery/?galAlbum=8.

Rodríguez, F., Rué, L. \& López, L. (2013). Situating the Communicative Methodology of Research in the Context of Public Science. International Review of Qualitative Research, 6(2), 307-322.

Romanov, V. S. (1990). Nuclear power and public opinion: Public information centres are part of new Soviet initiatives. IAEA Bulletin, 2, 19-22.

Schmid, S. (2006). Celebrating Tomorrow Today: The Peaceful Atom on Display in the Soviet Union. Social Studies of Science, 36(3), 331-365.

Schmid, S. (2011). Nuclear colonization?: Soviet technopolitics in the second world. In G. Hecht (Ed.), Entangled Geographies: Empire and Technopolitics in the Global Cold War (pp. 125-154). Cambridge, MA: MIT Press,

Schmid, S. (2012). Shaping the Soviet Experience of the Atomic Age: Nuclear Topics in Ogonyok, 1945-1965. In D. Van Lente (Ed.), The Nuclear Age in Popular Media (pp. 19-52). New York, NY: Palgrave MacMillan.

Shkandrij, M. (2009). Contemporary Ukrainian Art and the Twentieth-Century Avant-Garde. In L. M. L. Zaleska Onyshkevych, \& M. G. Rewakowicz (Eds.), Contemporary Ukraine on the Cultural Map of Europe (pp. 411-432). Armonk, NY: M.E. Sharpe.

Shulman, S. (2004). The Contours of Civic and Ethnic National Identification in Ukraine. Europe-Asia Studies, 56(1), 35-56.

Smith, M. (1991). Advertising the Atom. In M. Lacey (Ed.). Government and Environmental Politics: Essays on Historical Developments Since World War Two (pp. 233-262). Washington, DC: Wilson Center Press.

Smith, M. (1993). Making Time: Representations of Technology at the 1964 World's Fair. In R. Wightman Fox \& J. Lears (Eds.). The Power of Culture: Critical Essays in American History (pp. 223-244). Chicago, MI: University of Chicago Press.

Storm, A. (2014). Post-Industrial Landscape Scars. London, England: Palgrave Macmillan.

South Ukraine Nuclear Power Plant. (2018). Fotoalbom: Vidy Iuzhno-Ukrainskoi AES. Retrieved from http://www.sunpp.mk.ua/ru/photoalbum/yuu-aes.

South Ukraine Nuclear Power Plant. (2011, December 21). Mirnyi atom v risunkakh detei. Retrieved from https://www.sunpp.mk.ua/ru/news/news_sunpp/349.

South Ukraine Nuclear Power Plant. (2013, December 12). Pobedila "Atomnaia sem'ia Ukrainy." Retrieved from https://www.sunpp.mk.ua/ru/news/news_sunpp/1690.

Supreme Rada of Ukraine. (1990, August 2). Pro Moratorii na Budivnytstvo Novykh Atomnykh Elektrostantsii na Terytorii Ukraíns'koi RSR. Postanova no. 134XII. Retrieved from http://zakon2.rada.gov.ua/laws/show/134-12.

Supreme Rada of Ukraine. (1993, October 21). Pro Deiaki Zakhody Zabezpechennia Narodnoho Hospodarstva Elektroenerhiieiu. Postanova no. 3538-XII. Retrieved 
from

http://zakon2.rada.gov.ua/laws/show/3538-

12test=XX7MfyrCSgkyGEjIZiOe2vMyHI4Hks80msh8Ie6.

Sysyn, F. (1991). The Reemergence of the Ukrainian Nation and Cossack Mythology. Social Research, 58(4), 845-864.

The Royal Society. (1985). The Public Understanding of Science. Retrieved from https://royalsociety.org/ /media/Royal_Society_Content/policy/publications/19 85/10700.pdf.

Topçu, S. (2013). La France nucléaire. L'art de gouverner une technologie contestée. Paris, France: Seuil.

Tsentr obshchestvennoi informatsii po atomnoi energii. (1991a). Nedostatochnost' informatsii - odna iz prichin otritsatelnogo otnosheniia k AES. Informatsionnyi biulleten' Tsentra obshchestvennoi informatsii po atomnoi energii, 9, 79-81.

Tsentr obshchestvennoi informatsii po atomnoi energii. (1991b). Rezul'taty sotsiologicheskogo oprosa otnositel'no rekonstruktsii i dal'neishei ekspluatatsii Beloiarskoi AES i rekomendatsii razrabotannye Tsentra obshchestvennoi informatsii dlia informatsionno-spravochnoi gruppy AES. Moscow, USSR. As located in Tsentr dokumentatsii obshchestvennykh organizatsii Sverdlovskoi oblasti (Documentation Center on the Social Organizations of the Sverdlovsk Region, Russia), F. 4, O. 120, D. 215, L. 3-52.

UNIAN. (2016, December 20). Ukraina s nachala goda importirovala iz Shvetsii 34\% iadernogo topliva, ostal'noe - iz Rossii. Retrieved from http://economics.unian.net/energetics/1690377-ukraina-s-nachala-godaimportirovala-iz-shvetsii-34-yadernogo-topliva.html.

Van Orman, T. (2013). The role of Symbolic Clothing in Ukrainian Gender and Power. Studies in Slavic Cultures, XI, 11-12.

Wanner, C. (1998). Burden of Dreams: History and Identity in Post-Soviet Ukraine. University Park, PA: Penn State Press.

Weart, S. (1988). Nuclear Fear: A History of Images. Cambridge, MA: Harvard University Press.

Wilson, A. (1995). The Donbas between Ukraine and Russia: The Use of History in Political Disputes. Journal of Contemporary History, 30, 265-289.

World Nuclear Association. (2018). Nuclear Power in Ukraine. Retrieved from http://www.world-nuclear.org/information-library/country-profiles/countries-tz/ukraine.aspx.

Wynne, B. (1992). Misunderstood misunderstanding: social identities and public uptake of science. Public Understanding of Science, 1(3), 281-304.

Wynne, B. (1995). Public understanding of science. In S. Jasanoff et alii (Eds.), The Handbook of Science and Technology Studies (pp. 361-391). Thousand Oaks, CA: Sage Publications.

\section{Figures $^{69}$}

Figure 1: "Waiting for father from work," 13 y. o., 2014, Khmelnytska NPP competition.

Figure 2 : No name, 16 y. o., 2016, Khmelnytska NPP competition.

Figure 3 : "Remember the Past, Think of the Future", 13 y. o., 2016, Khmelnytska NPP competition.

\footnotetext{
${ }^{69}$ Permission to reproduce the following images has been requested.
} 